\title{
Urban Food Insecurity: The relationship between community resilience and urban agriculture
}

\author{
Anizah Mohd Salleh ${ }^{1,2}$, Nor Zalina Harun1, Sharina Abdul Halim³ \\ ${ }^{1}$ Institut Alam dan Tamadun Melayu, \\ 3Institut Alam Sekitar dan Pembangunan \\ Universiti Kebangsaan Malaysia, Malaysia \\ ${ }^{2}$ Fakulti Teknikal dan Vokasional, \\ Universiti Pendidikan Sultan Idris, Malaysia
}

anizahthesis@gmail.com, nzalina@ukm.edu.my,sharinahalim@ukm.edu.my

\begin{abstract}
This article presents the relationship between community resilience and urban agriculture as a strategy for food and nutrition security forthe vulnerable urban group. Through a systematic literature review and using thematic analysis, the study reveals four related domains identified as food security, food production, food flow, and resilience strategy. The community resiliency was presented through the contribution of urban agriculture as part of community preparedness, response, and recovery in short and long-term impacts. The study concludes that green spaces provision in a residential area act as a viable support system underlined the economic, social, and environment interaction
\end{abstract}

Keywords: urban agriculture; vulnerable urban group; community resilience; food insecurity

eISSN 2398-4279 @2020 The Authors. Published for AMER ABRA cE-Bs by e-International Publishing House, Ltd., UK. This is an open access article under the CC BY-NC-ND license (http://creativecommons.org/licenses/bync-nd/4.0/). Peer-review under responsibility of AMER (Association of Malaysian Environment-Behaviour Researchers), ABRA (Association of Behavioural Researchers on Asians) and $c E-B s$ (Centre for EnvironmentBehaviour Studies), Faculty of Architecture, Planning \& Surveying, Universiti Teknologi MARA, Malaysia.

DOI: https://doi.org/10.21834/ajqol.v5i18.206 


\subsection{Introduction}

The phenomenon of urbanization has become a topic in a changing environment. The changes can be seen through the increase of $55 \%$ world population, particularly in urban areas from 751 million in 1950 to 6.7 billion in 2050(United Nations, 2018b). The increase is subjected to the natural population growth, local and international migration, and expansion of urban settlement(Siwar et al., 2016; United Nations, 2018a).Among those factors, the projection of urban land expansion for the creation of the built environment is expected to the loss of 1.8 to $2.4 \%$ global agricultural land by 2030 (d'Amour et al., 2017).With $60 \%$ of the agricultural land situated in the peri-urban area, such a situation nonetheless creates competitive land use between agriculture and urban usage. It is influenced by macro factors of economic development such as income, informal economy, land use policy, and transportation cost(Seto et al., 2011).In details, rapid urban land expansion is seen as a significant threat to human survival and well-being (Szabo, 2015)that leads to the incidence of urban poverty (Siwar et al., 2016)and incapability to afford basic human needs of food, clothes, and shelters(Chamhuri et al., 2012; Mat and Othman, 2014; Siwar et al., 2016). As a result, it caused half of the urban population to live in an improper settlement with a lack of access to water and sanitation, insufficient living areas, and inadequate amenities (Liddle, 2017). Such a situation has further contributed to the food crisis of urban food insecurityamong the vulnerable urban group(Begum et al., 2011; Chamhuri et al., 2012; Islam and Siwar, 2012).

In response to the phenomenon, urban agriculture has become an initiative in overcoming the impact of food insecurity and acts as a centre for the sustainable food system.The contribution of urban agriculture is seen through the improvement of the economic, social, and environmental conditions of the urban area. Thisstatement is supported byRezai et al. (2016)on the potential of urban agriculture in reducing the food expenditure by providing an adequate amount of food sources, cost-effective food supply, and appropriate food nutrition.Recently,Othman et al. (2018)go beyond the economic aspect and expend into the motivational factor for urban agriculture which are in response to a healthy lifestyle through leisure and recreational activities that further enhance social bonding within the community.Another new finding from a study conducted byMcdougall et al. (2019)through life cycle analyses shows that urban agriculture has environmental benefits from non-food production through the reduction of greenhouse gas emission as well as improve urban biodiversity for urban habitat. The study is almost congruent withMackiewicz et al. (2019)by emphasizing that urban agriculture considers the sustainability aspect in its development,which further contributes to sustainable city development.

This study aims to examine in depth the capability of urban agriculture in combating the food crisis of urban food insecurity as well as to understand the relationship between community resilience and urban agriculture program. The objectives are (i) to identify the elements of food security and (ii) to explore the urban agriculture program that can be considered as community resilience strategy among the vulnerable urban group. As such, this study employed a qualitative approach through a systematic literature review of 
secondary resources and analyzed using thematic analysis. This document review process includes searching comprehensively available relevant evidence and secondly, filtering the evidence related to the scope of the study. In doing so, this study seeks to identify relevant and reliable research on urban agriculture, urban food insecurity, and community resilience in the context of thevulnerable urban group of low-income households.

\subsection{Literature Review}

\subsection{The implementation of urban agriculture by vulnerable urban group}

Urban agriculture or also known as urban farming represents agricultural activities within an urban setting. Based on the seminal work byMougeot (2000), urban agriculture was referred as "an industry located within (intra-urban) or on the fringe (peri-urban) of a town, a city or a metropolis, which grows or raises, processes and distributes a diversity of food and nonfood products, (re-)using largely human andmaterial resources, products and services found in and around that urban area, and in turn supplying human and material resources, products and services largely to that urban area". In the interim, urban farming is defined as a cultivation practice rather than as an industry(Othman et al., 2018).The agricultural activities involve planting, processing, and distributing the agricultural products of crop and livestock by using natural resourcesfor the benefit of surrounding communities (Othman et al., 2017). One could conclude that urban farming is focusing on the social and environmental aspects, while urban agriculture is more diverse by covering the economic, social, and environmental aspects. As for this study, urban agriculture is defined as any agricultural activity of food cultivation and animal husbandry in an urban area with multifunctional effects on the urban economy, society, and environment. It is acknowledged as a farming activity for self-consumption in response to the food crisis faced by the urban poor.

The various agricultural systems may involve in urban agriculture practices include horticulture, floriculture, forestry, aquaculture, and livestock, but mostly dominated by horticulture products(Orsini et al., 2013). It was mentioned by Ghazali (2013) and Mohd Hussain et al. (2018) who found edible low-maintenance species that are sustenance and survival plants such as lemongrass, turmeric, ginger, chilli, and long bean are planted in the backyard or house garden for culinary purposes. This situation led to the idea that urban agriculture is implemented as informal food supply system (Islam and Siwar, 2012), as it can be applied either in the backyard or kitchen garden, roadside cultivation, or open space cultivation (Kutiwa et al., 2010). Meanwhile, the selection of the types of urban agriculture practices varies depending on the location, scale, component, purpose, main activity, and complementary activity. Specifically, urban agriculture amongthe vulnerable urban group can be categorized into various types which are regularly cited as a community garden(Egli et al., 2016; Ramaloo et al., 2018), house garden(Ghazali, 2013; Mohd Hussain et al., 2018) and allotment garden(Holmer and Drescher, 2005; Mackiewicz et al., 2019). 
Excitingly, the emergence of a new agricultural approach contributes to the new forms of urban agriculture practices such as community-supported agriculture,a demonstration garden, institutional garden, guerrilla gardening, and squat farming(Buic et al., 2017; Trendov, 2018). It requires the integration of various farming techniques and continues training that involves medium to the high cost of machinery and maintenance (Mat and Othman, 2014)to ensure the success of the urban agriculture practices (Buic et al., 2017). However, the idea of innovative agriculture approach is not the essential aspect of urban agriculture for the vulnerable urban group. This condition is because their primary concern is on the socio-economic resolutions. The contribution of urban agriculture as the food supply is more vital than its potential as a paradigm for advanced agriculture practices. This phenomenon is subjected to the need to build community resilience by emphasizing the capability and adaptability of urban agriculture as an alternative solution to produce food supply for urban communities.

\subsection{Urban agriculture and the concept of community resilience}

Community resilience is the ability of an individual or community to adapt, recover, or collapse to the adversity, trauma, tragedy, threat, or stress(Omar Chong et al., 2018), particularly in this study refers to the stress on the food crisis. It deals with different topics related to economic development, social capital, information and communication, and community competence(Norris et al., 2008). The concept is divided into five spatial scales of individual, local, regional, national, and global, but often discussed in the context of local and community levels(Food and Agriculture Organization of the United Nations, 2017). This concept led to the systematic processes of community resilience by identifying, assessing, and analyzing the causal factors of the stress. Its role is to reduce exposure on the pressure, lessen the vulnerability of the community, wise management of land, improve preparedness towards the pressure, and as an early warning to the community(International Strategy for Disaster Reduction, 2009). Therefore, community resilience is the idea of determining strength or capability to overcome disturbance, community with strong capital, temporal factor, and level of achievement.

Resilience has the role of adapting the urban food insecurity stresses by strengthening the livelihood and survival of the vulnerable urban group (Begum et al., 2011). This association is driven by social protection which further recognized as one of the initiatives in sustainable development strategy. Social protection is defined as "the set of policies and programs designed to reduce poverty and vulnerability by promoting efficient labour markets, diminishing people's exposure to risks, and enhancing their capacity to protect themselves against hazards and interruption or loss of income"(Asian Development Bank, 2003). The process that involves social protection is preventing, managing, and overcoming adverse situations faced by people in order to have a good quality of life. It is implemented either by public or private organizations to prevent the onset shocks and stresses, mitigate the impacts, cope with the impacts, and transform the impacts by addressing the vulnerabilities (Holmes et al., 2007). Importantly, it can be assessed by exploring the contribution of urban agriculture as part of community preparedness, response, and 
recovery in short and long-term impacts. The contribution is yet has a close relationship with the assessment of community resilience.

For this reason, the consideration of resilience in urban agriculture practices varies considerably between food sovereignty, environmental sustainability, and community building. Urban agriculture has offered resilience capacity to support the economic stability in the household level through food diversification for the local food market (Barthel and Isendahl, 2013; Begum et al., 2011; Hashim et al., 2018). There is also some evidence that urban agriculture can improve ecological resilience through its potential as ecosystem services of provisioning, regulating, supporting, and cultural services(Barthel et al., 2015; Wu and Chang, 2018). Simultaneously, it promotes social resilience that could empower young adults to understand and aware of the role and contribution of urban agriculture for the enhancement of socio-cultural ecosystem services within urban context (Abdullah Ayeop et al., 2018; Martin and Vold, 2018). These could be conceptualized as a significant driver for sustainability and resiliency of urban communities, which can exist at multiple scales with the diverse function of urban agriculture.

\subsection{Methodology}

This study employs a qualitative approach through a systematic literature review that consists of three phases of identification, screening, and eligibility, as explains below:

\subsection{Identification}

The first phase required to retrieve a broad set of documents through the identification process. The identification process includes comprehensive searching of available and relevant documents using the database Web of Science, one of the leading indexing system (Samsuddin et al., 2020). An advanced search query was further performed by using a search string strategy of phrase searching and the Boolean operator. It involves the filtration of all documents related to the scope of the study. In doing so, this study seeks to identify relevant, transparency, and reliable documents through the search strategy of a set of keywords on urban agriculture, urban farming, food insecurity, community resilience, and urban poor. The term "urban agriculture" or "urban farming" was entered in every search string in order to retrieve specific topics in various document types, such as article, proceedings paper, review, editorial material, book chapter, and book.

\subsection{Screening}

The second phase consisted of screening processes that encompass double counting and screening criteria on the article collected during the identification process. Double counting of documents was avoided and removed from the list of a sample as the possibility to have similar documentsdue to the usage of the same keywords(Meijer and Bolivar 2016). Meanwhile, screening criteria involve the inclusion and exclusion of the article that has been determined through its criteria with the assistance of the searching tool in the database (Samsuddin et al., 2020). Three criteria are used for the inclusion of studies in order to 
identify suitable articles to be selected and analyzed in the systematic review process, as shown in Table 1.

Table 1: The inclusion and exclusion criteria

\begin{tabular}{lll}
\hline Criterion & Inclusion & Exclusion \\
\hline Timeline & Between 2010 and 2019 & $<2010$ \\
\hline Document types & Open access article (research article & Non-open access article \\
\hline Language & English & Non-English \\
\hline & & (Source: Author)
\end{tabular}

\subsection{Eligibility}

The third phase involved the selection of only relevant articles to the aim of the study. It consisted ofthorough manual checking of the right keywords and based on the abstract. The abstract and introduction were reviewed, while the overall structure of the article was checked. Besides, those articles of specific sciences articles without examining any of the domainswere eliminated from the sample. Only social sciences articles were reviewed to ensure eligibility as this study is focusing on the in-depth explanation of the relationship between urban agriculture and community resilience.

\subsection{Research limitation}

The limit of the systematic literature review on community resilience has been implemented on the general understanding and its practices from agricultural perspectives. First, the meaning of community resilience in this study refers to the ability of the community to implement and adopt urban agriculture practices as an alternative solution for the food crisis of urban food insecurity. Second, types of urban agriculture practices limit the range of practices that only require low-cost machinery and maintenance subjected to the land availability to ensure the resiliency.

\subsection{Results}

A systematic review process has resulted in a sample of 176 documents dealing with a variety of different aspects of urban agriculture and community resilience. Attention to this subject, those documents were screened and refined for its double counting and screening criteria. The processes resulted in a sample of 132 documents are removed from the collection. Out of the 176 included materials, only 44 articles are applicable and thoroughly reviewed by excluding any articles that did not meet the criteria on the contribution of urban agriculture for community resilience.

As a result, in total, 15 articles were collected and analyzed as a sample of the urban agriculture practices that considered as a program for community resilience (Table 2).In details, the result produced a comprehensive analysis of the current urban agri-resilience strategy and investigation on the urban agriculture, the concept of community resilience, and its relationship with social protectionfor the vulnerable urban group in adapting to the urban food insecurity crisis. The review resulted in 4 main themes and 14 sub-themes of 
food security (4 sub-themes), food production ( 3 sub-themes), food flow (4 sub-themes), and resilience strategy ( 3 sub-themes) as shown in Table 3.

Table 2: The systematic literature review process of three phases

\begin{tabular}{|c|c|c|c|c|}
\hline \multirow[t]{2}{*}{ Search string } & & \multicolumn{3}{|c|}{ Phase } \\
\hline & & Identification & Screening & Eligibility \\
\hline \multirow{7}{*}{$\begin{array}{l}\text { Phase searching and } \\
\text { the Boolean operator }\end{array}$} & "Urban Agriculture" AND Food Insecurity & 87 & 16 & 5 \\
\hline & "Urban Farming" AND Food Insecurity & 14 & 5 & 1 \\
\hline & $\begin{array}{l}\text { "Urban Agriculture" AND Food Insecurity AND } \\
\text { Urban Poor }\end{array}$ & 24 & 4 & 2 \\
\hline & $\begin{array}{l}\text { "Urban Farming" AND Food Insecurity AND } \\
\text { Urban Poor }\end{array}$ & 6 & 2 & 2 \\
\hline & "Urban Agriculture" AND Community Resilience & 42 & 14 & 4 \\
\hline & "Urban Farming" AND Community Resilience & 3 & 3 & 1 \\
\hline & Total & 176 & 44 & 15 \\
\hline
\end{tabular}

(Source: Author)

From this point, urban agriculture demonstrates the element of food security that is commonly found to fall into three main categories of food i) availability, ii) accessibility and iii) utilization. Remarkably, this study discovered an emphasis on another category as food stability that is rarely being underlined before. This finding underpins the logic of urban agriculture with multifunctional internal and external impacts for building community resilience. The discovery suggests that food stability should also be embraced as part of the element of food security other than food availability, accessibility, and utilization for the household and community level (Figure 1).

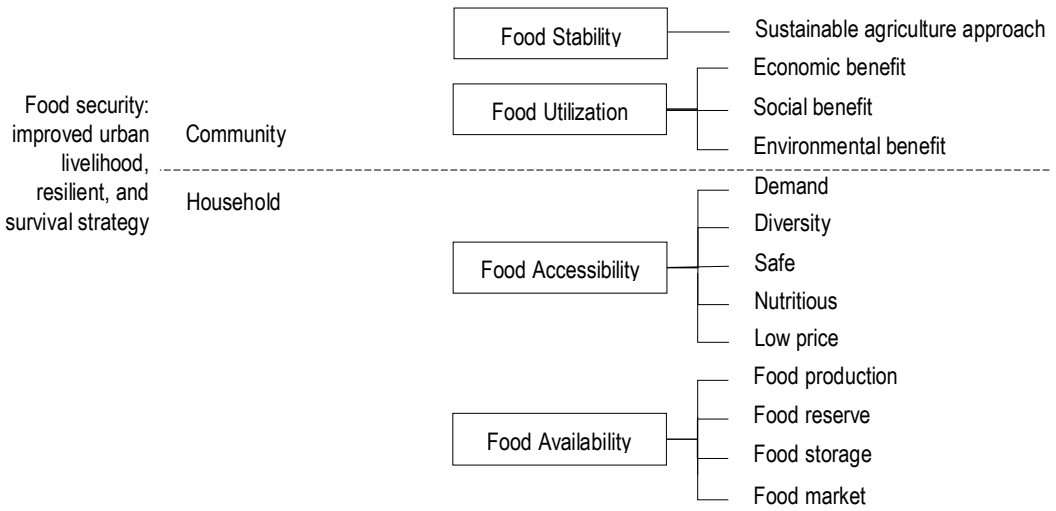

Figure 1:Elements that intertwined between urban agriculture and community resilience

(Source: Author) 
Table 3: Table of findings

\begin{tabular}{|c|c|c|c|c|c|c|c|c|c|c|c|c|c|c|}
\hline \multirow[t]{2}{*}{ Author } & \multicolumn{4}{|c|}{ Food security } & \multicolumn{3}{|c|}{ Food production } & \multicolumn{4}{|c|}{ Food flow } & \multicolumn{3}{|c|}{$\begin{array}{c}\text { Resilience } \\
\text { strategy }\end{array}$} \\
\hline & FA & $\mathrm{FC}$ & $\mathrm{FU}$ & FS & SF & FR & $\mathrm{CC}$ & SC & $\mathrm{FE}$ & LM & DT & SA & SN & $\mathrm{SS}$ \\
\hline $\begin{array}{l}\text { Kutiwa et al. } \\
(2010)\end{array}$ & 1 & & 1 & & 1 & 1 & 1 & 1 & & & & & & 1 \\
\hline $\begin{array}{l}\text { Talukder et al. } \\
(2010)\end{array}$ & 1 & 1 & 1 & & & 1 & 1 & l & & 1 & & I & 1 & \\
\hline $\begin{array}{l}\text { Shillington } \\
(2012)\end{array}$ & 1 & & l & & & 1 & 1 & 1 & & & & & & 1 \\
\hline $\begin{array}{l}\text { Meenar \& } \\
\text { Hoover (2012) }\end{array}$ & 1 & 1 & 1 & & & 1 & 1 & 1 & & 1 & I & I & 1 & \\
\hline Pulliat (2015) & 1 & 1 & 1 & & I & 1 & 1 & 1 & & 1 & & & 1 & 1 \\
\hline $\begin{array}{l}\text { Specht et al. } \\
(2016)\end{array}$ & 1 & 1 & 1 & 1 & & 1 & 1 & l & & 1 & & l & & \\
\hline $\begin{array}{l}\text { Gasperi et al. } \\
(2016)\end{array}$ & 1 & & 1 & 1 & & 1 & & 1 & & & & 1 & & 1 \\
\hline $\begin{array}{l}\text { Bussell et al. } \\
(2017)\end{array}$ & 1 & 1 & & & & 1 & & 1 & 1 & 1 & I & & 1 & 1 \\
\hline $\begin{array}{l}\text { Martin \& Vold } \\
(2018)\end{array}$ & 1 & 1 & 1 & & & 1 & 1 & 1 & & 1 & & 1 & 1 & \\
\hline $\begin{array}{l}\text { Ramaloo et al. } \\
(2018)\end{array}$ & 1 & 1 & 1 & 1 & & 1 & l & l & & 1 & & 1 & & \\
\hline $\begin{array}{l}\text { Moucheraud et } \\
\text { al. (2019) }\end{array}$ & 1 & 1 & l & & 1 & I & 1 & I & & 1 & & & & 1 \\
\hline $\begin{array}{l}\text { Calvet-Mir \& } \\
\text { March (2019) }\end{array}$ & 1 & & & I & & 1 & & l & & & & 1 & & \\
\hline $\begin{array}{l}\text { Khumalo \& } \\
\text { Sibanda (2019) }\end{array}$ & 1 & 1 & 1 & & I & & & 1 & & 1 & & & 1 & 1 \\
\hline $\begin{array}{l}\text { Ulug \& Horlings } \\
\text { (2019) }\end{array}$ & 1 & 1 & 1 & 1 & & 1 & & 1 & & 1 & I & 1 & & \\
\hline $\begin{array}{l}\text { Diehl et al. } \\
(2019)\end{array}$ & 1 & 1 & & I & & 1 & 1 & l & 1 & 1 & 1 & I & 1 & 1 \\
\hline Total & 15 & 11 & 12 & 6 & 4 & 14 & 10 & 15 & 2 & 11 & 4 & 9 & 7 & 8 \\
\hline $\begin{array}{l}\text { Food Availability (FA) } \\
\text { Food Accessibility (FC } \\
\text { Food Utilization (FU) }\end{array}$ & & $\begin{array}{l}\text { Food S } \\
\text { Staple } \\
\text { Food R }\end{array}$ & $\begin{array}{l}\text { ility (FS) } \\
\text { od (SF) } \\
\text { tine (FR) }\end{array}$ & & $\begin{array}{l}\text { Culina } \\
\text { Self-C } \\
\text { Food }\end{array}$ & $\begin{array}{l}\text { Culture } \\
\text { Isumpti } \\
\text { change }\end{array}$ & $\begin{array}{l}\text { (CC) } \\
\text { (SC) } \\
\text { FE) } \\
\text { Author) }\end{array}$ & & $\begin{array}{l}\text { Marke } \\
\text { tion (D } \\
\text { Assis }\end{array}$ & $\begin{array}{l}\text { (LM) } \\
\text { nce (SA) }\end{array}$ & & $\begin{array}{l}\text { Safety N } \\
\text { Survival }\end{array}$ & $\begin{array}{l}\text { S (SN) } \\
\text { rategy }\end{array}$ & \\
\hline
\end{tabular}

Table 4: Interrelationship between farming system and resilience strategy

\begin{tabular}{|c|c|c|c|c|c|c|}
\hline \multirow[b]{2}{*}{ Resilience strategy } & \multicolumn{6}{|c|}{ Farming types or area } \\
\hline & Backyard & Roadside & $\begin{array}{l}\text { House } \\
\text { garden }\end{array}$ & $\begin{array}{c}\text { Community } \\
\text { garden }\end{array}$ & $\begin{array}{c}\text { Allotment } \\
\text { garden }\end{array}$ & $\begin{array}{c}\text { Abandoned } \\
\text { area }\end{array}$ \\
\hline Social assistance & & & 1 & 1 & & 1 \\
\hline Safety nets & & & 1 & 1 & 1 & \\
\hline Survival strategy & 1 & 1 & 1 & 1 & 1 & 1 \\
\hline
\end{tabular}

(Source: Author)

Apart from that, the fulfilment of these elements thus highlighted the competency of urban agriculture as an initiative program for building community resilience. In this way, the number of studies on urban agriculture that contribute to the documentation of a resilience strategy on social assistance, safety nets, and survival strategy is equally developed. The formation of these sub-themes is directed by the other themes of food production and food flow (Table 3). Accordingly, the implementation of urban agriculture for each resilience 
strategy is partially influenced by the farming types subjected to the availability of land area for agricultural activities (Table 4).

\subsection{Discussion}

\subsection{The dynamic of food security in urban agriculture}

\subsubsection{Physical availability of food}

Food availability involves the process of food production, distribution, and marketing with the availability and usage of natural, human, and economic resources. It addresses the appropriate quality and sufficient quantity of the food products. The motivation to implement urban agriculture within the housing area is related to one of the basic human needs for each household which is food that is getting higher at a price, lower in quality, and scarce in quantity (Kutiwa et al., 2010). Consequently, food production getting worse in the condition where natural resource is limited and needed for an alternative to overcome that situation.For this reason, the provision of food availabilityconsists of a food market, food storage, food reserve, and food production. Nevertheless, the resiliency of food availability is subjected to the balanced food supply and demand among the household and community of the vulnerable urban group. The high availability of food items is further offering a sufficient and variety of food supply within the community, which can be found at the local markets or street vendors.

\subsubsection{Economic and physical access to food}

Food accessibility explains on the ability of urban communities to access for food with a walkable or manageable distance using affordable and convenient transportation. With this explanation, urban agriculture is acknowledged as an informal food supply system that can be implemented within a house compound or neighbourhood area(Ghazali, 2013; Islam and Siwar, 2012).As a result, the availability of food supply is accessible, thus could be influenced by the purchasing power (low price, nutritious, and safe) and food allocation (diversity and demand). This condition also contributes to a variety of healthy food and reduces the intake of unhealthy food that can easily be accessed by the community. Fortunately, this conditioncould facilitate urban dwellers with diverse and nutritious food preference, specifically a healthy diet for an active life. The diversity, safe, and nutritious food sources which can be gained for self-consumption or traded with low price delivers sufficient food demand for the whole family of the household.

\subsubsection{Individual and community utilization of food}

The concern on food utilization is often used interchangeably with environmental, social, and economic benefits of urban agriculture. The capability is focused on the individual and community, particularly for the improvement of community development such as healthy lifestyle, social interaction, and economic stability. The fact that the potential of urban 
agriculture is motivated by the economic, social, and environmental benefits has been studied by many researchers throughout the world(Kutiwa et al., 2010; Mackiewicz et al., 2019; Mcdougall et al., 2019; Othman et al., 2018; Rezai et al., 2016; Talukder et al., 2010). Therefore, it is important to keep in mind that the spectrum of urban agriculture as part of a sustainable food systemis simultaneously able to overcome the urban food insecurity crisis. It is subjected to the focus of food utilization that emphasizesthe proper use of food, proper food processing, proper storage techniques, as well as adequate knowledge on the food application.

\subsubsection{Stability of agricultural practices over time}

Food stability is depending on the agricultural practices itself either employs good or bad agricultural practices through sustainable or unsustainable agriculture approach, respectively. Notably, the desire to implement urban agriculture is motivated by fresh food production, sustainable food, reduce food cost, environmental benefits, alternative for exercise, outdoor time, learning centre, socializing, and cultural reasons (Duchemin et al., 2008; Mcdougall et al., 2019). It shows that the implementation of urban agriculture is mainly related to the social, economic, and environmental aspects that contribute to the improvement of quality of life. This situation further portrays the urban agriculture system to be either short or long-term non-emergency responses depending on the needs of the situation. The capability of urban agriculture to adapt and recover from any possible adverse conditions such as climatic, economic, social, and political factors can show its positive stability.

\subsection{Community resilience strategy of urban agriculture}

\subsubsection{Urban agriculture: a social program for survival livelihood}

With the demand for food supply which is expected to increase by $50 \%$ to $60 \%$ parallel with the increase of urban population, the need for building up a community resilience among thevulnerable urban group is perceived as a significant task (Tefft et al., 2017). The resiliency can be emphasized by strengthening the livelihood and survival of poor urban communities. The efforts on the implementation of urban agriculture made by the urban dwellers are contributing to the reduction of struggle on urban food insecurity. Positively, continuous practice and sustain of urban agriculture as an informal food supply system offer a resilient practice can enhance the social well-being of the urban dwellers. The urgency on the implementation of urban agriculture for survival among the vulnerable urban group are applied by the low-income households in Harare, Zimbabwe, who implement their farming system despite urban legislation (Kutiwa et al., 2010). Urban agriculture is being practised either in the backyard or kitchen area, roadside, urban fridge, abandoned area, or even open spaces(Gasperi et al., 2016; Kutiwa et al., 2010; Pulliat, 2015). The resiliency of urban agriculture practices in that area only requires minimal agricultural innovation with low cost of machinery and maintenance, which are affordable for the poor urban communities. 
From a social protection perspective, the informal food supply system of urban agriculture act as a natural food bank for a survival strategy. It portrays a close relationship with food availability by presenting the continuous existence of food production, food reserves, food storages, and food markets. The implementation is subjected to the difficulty in buying sufficient, safe, and nutritious food sources based on their economic conditions (Duchemin et al., 2008; Ghazali, 2013; Talukder et al., 2010). The survival of poor urban communities is shown through the cultivation of primary crop production, which is a staple food(Khumalo and Sibanda, 2019; Kutiwa et al., 2010; Moucheraud et al., 2019; Pulliat, 2015). It is usually planted for present self-consumption, not for domestic or store for future use. This practice is influenced by the location and size of the urban agriculture area, which is implemented in any possible area that could be used as a farming plot. Besides, poor urban communities in Hanoi, Vietnam, resorted to urban agriculture as a coping strategy by being able to fulfil the needs of basic food requirements or food reserves (Pulliat, 2015). It becomes a significant source of fresh food as it contributes to food production and food reserve as well as for human health in terms of dietary diversity.

\subsubsection{Urban agriculture: an economic program for social safety nets}

Building community resilience through urban agriculture is related to the community capacities that require various initiatives in preparing and empowering the community. Social safety nets are encouraging the adoption of innovative agricultural initiatives that could empower the vulnerable urban group. The initiatives should be able to relieve the food crisis by reducing food expenditure and encourage food diversification of various agrobased products.For instance, vegetables such as morning glory, tomatoes, cucumber, and pumpkin are the most popular food product planted by urban communities in Hanoi (Pulliat, 2015). Meanwhile, the allotment garden in the Philippines focused on the food production of vegetables and fruits such as banana, papaya, and pineapple (Holmer and Drescher, 2005). Even though the price for those vegetables and fruits is low, the availability of the product could reduce the food expenditure as the products are consumed daily.It is important to point out that urban agriculture is considered as a local urban food system and its ability to producing, processing, and distributing the food product either for self-consumption or commercial value.

Concerning the contribution from an economic perspective, the more significant benefit of urban agriculture is classified as early as part of a hobby which later spread as social development initiatives. The development of a small enterprise is further providing an opportunity for the improvement of local economic.Consequently, the cooperation from public or private organizations to produce variousagro-based productsbecame a platform as well as safety nets for the vulnerable urban group. The promotion of entrepreneurship of small enterprise through the engagement of economic activity with the industrial sector could support the resilience strategy of this vulnerable urban group. For instance, the initiatives are done by Berlin metropolitan via direct marketing or regular retailer, community-supported agriculture, and 'pick your own' program (Specht et al., 2016), to allow on-site experience onbuy and sell activities by choosing the food producers 
themselves. Furthermore, most of the individual farmers tended to farm and sold their agricultural products of fruits and chicken for small enterprises (Khumalo and Sibanda, 2019; Meenar et al., 2017; Pulliat, 2015). This is because both products are considered as expensive foodstuffs that have great potential to create additional income that can be sold in the local market.

\subsubsection{Urban agriculture: an environmental program for sustainable agriculture support}

In developed countries where urban agriculture has been widely practised, the idea of sustainability is strongly connected or incorporated into urban agriculture development. The environmental strategy, particularly on sustainable agriculture approach, can be achieved through social assistance. Social assistance is a set of programs targeted to the poor community through a community-based strategy. It consists of governmental and nongovernmental support, individual and community cooperation, continuous workshop from institution and organization, hands-on training from the volunteer and association, and sponsorship on agricultural tools for the development of suitable urban agriculture practices. The focus is an invention of the food aid program for short and long-term non-emergency responses, mainly to improve the condition of the vulnerable urban group. The program is conducted through the adoption of urban agriculture on waste management and organic farming by referring to a sustainable agriculture approach.

The environmental strategy of social assistance in waste management provides an indirect impact on the environmental aspect. The workshop on local culture facilitates education and training to the poor urban communities for the preparation of sustainable local food systems that are resilient for those vulnerable urban group (Holmer and Drescher, 2005). It engages the collaboration of the communities, neighbourhood association, and municipal administration to provide an adequate amount of stable food for the poor urban communities. In a study conducted by Holmer and Drescher (2005), the development of allotment gardens in Cagayan de Oro, Philippines is developed by the UN-Habitat Sustainable Cities Programme and supported by the city district as well as institutional agency in addressing the challenges of urban environmental management and food insecurity. The urban agriculture development consists of composting management from the household waste to inspire the usage of compost product rather than a chemical product. It is similar to the study of Ramaloo et al. (2018) initiated by the Penang state government in Malaysia. The idea of producing safe and nutritious food is practised through the sustainable agriculture approach of organic farming techniques. The Penang Department of Agriculture is not encouraging the urban farmers to use any pesticide or chemical fertilizer in their food products, which are regularly supervised by the government officers. As a result, the Urban Farming Project of Taman DesaDamai is acknowledged as the first area in Malaysia to obtain the Malaysian Organic Scheme Certificate in 2013. 


\subsection{Conclusion}

This paper presents asystematic review of the urban agriculture program that acknowledged as community resilience strategy in combating food insecurity. It reveals a remarkable addition of food stability as another element of food security other than food availability, accessibility, and utilization. This paper also provides detail insights into what happens in practices.By referring to the socio-economic conditionand example of an urban agriculture program, the most appropriate types of urban agriculture to be practised bythe vulnerable urban group is house garden, community garden, and allotment garden. However, the suitability is depending on the housing types and the availability of space for agriculture activity.Besides, most of thevulnerable urban group of low-income households in developing countries are staying in low-cost high-rise housing, in which they do not have their private land for agricultural activities. Hence, the urban food system for each urban area in response to the urban food insecurity is influenced by its evolution, management, and performance. This is subjected to the condition that food insecurity can be tackled effectively when natural resources are used sustainably in an equitable manner to meet human needs.

As a recommendation, the role of sustainable development strategy in uplifting resiliency is considered as part of an emergency or non-emergency response.The response can be categorized into short and long-term responsesof the economic, social, and environmental impact of the urban agriculture program. Accordingly, the socio-economic impact of urban agriculture is measured as short-term responses. The urban food system of urban agriculture practices can guarantee the accessibility and affordability of continuous food production to a low-income household. The availability of fresh food product that is safe and nutritious is encouraging for a healthy lifestyle.Meanwhile, small enterprises become an additional source of income at critical conditions. In the interim, the long-term response can be seen through the potential of urban agriculture as a platform for community engagement and sustainable livelihood. This strategy is emphasizing the importance of green spaces in a residential areaas a viable social support system that is underlining the interaction between economic, social, and environment.

Therefore, possible suggestions for future research is to facilitate the process of building a resilient community in a changing environment by strengthening the coordination among individual, community, and organization. In this case, all parties could play their role in bringing up the vulnerable urban group to work together on urban agriculture practices as an initial exposure such as community project, competition, and knowledge or skills sharing sessions. For example, the initiatives can be done through the sharing knowledge and continuous effort by related agencies like the Agricultural Department on the benefits of urban agriculture. The exposure should be actively presented to the public on the social media platform of social networking, photo sharing, and video sharing. It further improves the knowledge and skills of the local food systems, specifically as the preparation for the unexpected food crisis through a sustainable agriculture approach. Other than that, the realization of the importance and contribution of sustainable agriculture can be shared during the workshop and training as well as giving continuous consultation on the recent approach in sustainable agriculture. From a housing development perspective, it can be 
emphasized by providing a land area within a residential area, specifically for urban agriculture activities through proper legislation. Hence, the availability of land area could be a motivational factor on the desire among the vulnerable urban group to develop their urban agricultural area in facing the issues of food insecurity.

\section{Acknowledgement}

The authors thank Universiti Pendidikan Sultan Idris and Kementerian Pendidikan Malaysia (Pendidikan Tinggi) for financial assistance, and UniversitiKebangsaan Malaysia is gratefully acknowledged for guidance and suggestions.

\section{References}

Abdullah Ayeop, S. M., Zainol, H., \& Mohd Hussain, N. H. (2018). The Components of Social Dimension for Community Gardens in Housing Residential. Environment-Behaviour Proceedings Journal, 3(7), $209-218$. https://doi.org/https://doi.org/10.21834/e-bpj.v3i7.1253

Asian Development Bank. (2003). Social Protection. Retrieved from http://usicd.org/doc/social-protection.pdf

Barthel, S., \&lsendahl, C. (2013). Urban gardens, agriculture, and water management: Sources of resilience for long-term food security in cities. Ecological Economics, 86, 224-234. https://doi.org/10.1016/j.ecolecon.2012.06.018

Barthel, S., Parker, J., \&Ernstson, H. (2015). Food and Green Space in Cities: A Resilience Lens on Gardens and Urban Environmental Movements. Urban Studies, 52(7), 1321-1338.

Begum, R. A., Siwar, C., Abidin, R. D. Z. R. Z., \& Pereira, J. J. (2011). Vulnerability of climate change and hardcore poverty in Malaysia. Journal of Environmental Science and Technology, 4(2), 112-117. https://doi.org/10.3923/jest.2011.112.117

Buic, M., Cunk, K., Kozina, J., Kumer, P., Kozlan, A., Lintzmeyer, F., ... Zamfira, R. (2017). Approaching urban agriculture as a social innovation. Guidelines for the development and implementation of an action plan.

Bussell, M. R., Bliesner, J., \& Pezzoli, K. (2017). UC pursues rooted research with a nonprofit, links the many benefits of community gardens. California Agriculture, 71(3), 139-147.

Calvet-Mir, L., \& March, H. (2019). Crisis and post-crisis urban gardening initiatives from a Southern European perspective: The case of Barcelona. European Urban and Regional Studies, 26(1), 97-112.

Chamhuri, N. H., Abdul Karim, H., \& Hamdan, H. (2012). Conceptual Framework of Urban Poverty Reduction: A review of literature. Procedia - Social and Behavioral Sciences, 68, 804-814. https://doi.org/10.1016/j.sbspro.2012.12.268

d'Amour, C. B., Reitsma, F., Baiocchi, G., Barthel, S., Guneralp, B., Erb, K.-H., ... Seto, K. C. (2017). Future urban land expansion and implications for global croplands. Sustainability Science, 114(34), 8939-8944. https://doi.org/https://doi.org/10.1073/pnas.1606036114

Diehl, J. A., Oviatt, K., Chandra, A. J., \& Kaur, H. (2019). Household Food Consumption Patterns and Food Security among Low-Income Migrant Urban Farmers in Delhi, Jakarta, and Quito. Sustainability, 11(1378). https://doi.org/10.3390/su11051378 
Duchemin, E., Wegmuller, F., \& Legault, A. M. (2008). Urban agriculture: multi-dimensional tools for social development in poor neighbourhoods. Field Actions Science Reports, 1, 43-52.

Egli, V., Oliver, M., \&Tautolo, E. (2016). The development of a model of community garden benefits to wellbeing. Preventive Medicine Reports, 3, 348-352. https://doi.org/10.1016/j.pmedr.2016.04.005

Food and Agriculture Organization of the United Nations. (2017). The future of food and agriculture. Trends and challenges. Rome.

Gasperi, D., Pennisi, G., Rizzati, N., Magrefi, F., Bazzocchi, G., Mezzacapo, U., ... Gianquinto, G. (2016). Towards Regenerated and Productive Vacant Areas through Urban Horticulture: Lessons from Bologna, Italy. Sustainability, 8(1347).

Ghazali, S. (2013). House Garden as a Symbol of Place, Identity and Sense of Belonging for Low-Cost Flat Residents in Urbanizing Malaysia. International Journal of Social Science and Humanity, 3(2), 171-175. https://doi.org/10.7763/ijssh.2013.V3.221

Hashim, N. H., Mohd Hussain, N. H., \& Ismail, A. (2018). The Rise of Rooftop Urban Farming at George Town, Penang. Environment-Behaviour Proceedings Journal, 3(7), 351-355. https://doi.org/https://doi.org/10.21834/ebpj.v3i7.1242

Holmer, R. J., \& Drescher, A. (2005). Building Food-Secure Neighbourhoods: the role of allotment gardens. UAMagazine, (December), 19-20.

Holmes, R., Farrington, J., \& Slater, R. (2007). Social Protection and Growth: The Case of Agriculture. IDS Bulletin, $38(3)$.

International Strategy for Disaster Reduction. (2009). UNISDR Terminoology on Disaster Risk Reduction. International Stratergy for Disaster Reduction (ISDR). Retrieved from www.unisdr.org/publications

Islam, R., \&Siwar, C. (2012). The Analysis of Urban Agriculture Development in Malaysia. Advances in Environmental Biology, 6(3), 1068-1078.

Khumalo, N. Z., \& Sibanda, M. (2019). Does Urban and Peri-Urban Agriculture Contribute to Household Food Security? An Assessment of the Food Security Status of Households in Tongaat, eThekwini Municipality. Sustainability, 11(1082). https://doi.org/10.3390/su11041082

Kutiwa, S., Boon, E., \&Devuyst, D. (2010). Urban Agriculture in Low Income Households of Harare: An Adaptive Response to Economic Crisis. Journal of Human Ecology, 32(2), 85-96.

Liddle, B. (2017). Urbanization and Inequality/Poverty. Urban Science, 1(35). https://doi.org/10.3390/urbansci1040035

Mackiewicz, B., Asuero, R. P., \&Almonacid, A. G. (2019). Urban agriculture as the path to sustainable city development. Insight into allotment gardens in Andalusia. Quaestiones Geographicae, 38(2), 121-136. https://doi.org/10.2478/quageo-2019-0020

Martin, W., \&Vold, L. (2018). Building capacity through urban agriculture: report on the askîy project. Health Promotion and Chronic Disease Prevention in Canada, 38(1).

Mat, B., \& Othman, Z. (2014). Regional cooperation in addressing food security issues in Southeast Asia: Malaysian perspectives. Malaysian Journal of Society and Space, 10(6), 37-47. 
Mcdougall, R., Kristiansen, P., \& Rader, R. (2019). Small-scale urban agriculture results in high yields but requires judicious management of inputs to achieve sustainability. Proceedings of the National Academy of Sciences, 116(1), 129-134. https://doi.org/10.1073/pnas.1809707115

Meenar, M., Morales, A., \&Bonarek, L. (2017). Regulatory Practices of Urban Agriculture: A Connection to Planning and Policy. Journal of the American Planning Association, 83(4), 389-403. https://doi.org/10.1080/01944363.2017.1369359

Meenar, M. R., \& Hoover, B. M. (2012). Community food security via urban agriculture: Understanding people, place, economy, and accessibility from a food justice perspective. Journal of Agriculture, Food Systems, and Community Development, 3(1).

Meijer, A., \& Bolivar, M. P. R. (2016). Governing the smart city: a review of the literature on smart urban governance. International Review of Administrative Sciences, 82(2), 392-408. https://doi.org/10.1177/0020852314564308

Mohd Hussain, N. H., Amir, A. F., Mt Akhir, N., \& Ibrahim, K. A. (2018). Between Survival and Sustenance: Plants for Recycle Edible Garden at Masjid As-Siddiq, Seri Iskandar, Perak, Malaysia. Environment-Behaviour Proceedings Journal, 3(7), 45-52. https://doi.org/https://doi.org/10.21834/e-bpj.v3i7.1286

Moucheraud, C., Chandyo, R. K., Henjum, S., Strand, T. A., Ulak, M., Fawzi, W. W., ... Thorne-Lyman, A. L. (2019). Engagement in Agriculture Protects Against Food Insecurity and Malnutrition in Peri-Urban Nepal. Current Development in Nutrition, 3.

Mougeot, L. J. A. (2000). Urban Agriculture: Definition, Presence, Potential and Risks, and Policy Challenges.

Norris, F. H., Stevens, S. P., Pfefferbaum, B., Wyche, K. F., \&Pfefferbaum, R. L. (2008). Community Resilience as a Metaphor, Theory, Set of Capacities, and Strategy for Disaster Readiness. American Journal of Community Psychology, 41, 127-150. https://doi.org/10.1007/s10464-007-9156-6

Omar Chong, N., Kamarudin, K. H., \& Abd Wahid, S. N. (2018). Framework Considerations for Community Resilient Towards Disaster in Malaysia. Procedia Engineering, 212, 165-172. https://doi.org/10.1016/j.proeng.2018.01.022

Orsini, F., Kahane, R., Nono-Womdim, R., \&Gianquinto, G. (2013). Urban agriculture in the developing world: a review. Agronomy for Sustainable Development. https://doi.org/10.1007/s13593-013-0143-z

Othman, N., Latip, R. A., Ariffin, M. H., \& Mohamed, N. (2017). Expectancy in Urban Farming Engagement. Environment-Behaviour Proceedings Journal, 2(6), 335-340. https://doi.org/10.21834/e-bpj.v2i6.948

Othman, N., Mohamad, M., Latip, R. A., \&Ariffin, M. H. (2018). Urban farming activity towards sustainable wellbeing of urban dwellers. IOP Conference Series: Earth and Environmental Science, 117.

Pulliat, G. (2015). Food securitization and urban agriculture in Hanoi (Vietnam). Articulo - Journal of Urban Research, (7).

Ramaloo, P., Choong, Y. L., Siwar, C., \&lsahak, A. (2018). Perception of Community Residents on SupportingUrban Agriculture in Malaysian City: Case Study at Bukit Mertajam. JurnalPengurusan, 53.

Rezai, G., Shamsudin, M. N., \& Mohamed, Z. (2016). Urban Agriculture: A Way Forward to Food and Nutrition Security in Malaysia. Procedia - Social and Behavioral Sciences, 216, 39-45. https://doi.org/10.1016/j.sbspro.2015.12.006 
Samsuddin, S. F., Mohamed Shaffril, H. A., \&Fauzi, A. (2020). Heigh-ho, heigh-ho, to the rural libraries we go! - a systematic literature review. Library and Information Science Research, 42. https://doi.org/https://doi.org/10.1016/j.lisr.2019.100997

Seto, K. C., Fragkias, M., Guneralp, B., \& Reilly, M. K. (2011). A meta-analysis of global urban land expansion. PLoS One, 6(8).

Shillington, L. J. (2012). Right to food, right to the city: Household urban agriculture, and socionatural metabolism in Managua, Nicaragua. Geoforum, (March).

Siwar, C., Ahmed, F., Bashawir, A., \& Mia, M. S. (2016). Urbanization and Urban Poverty in Malaysia: Consequences and Vulnerability. Journal of Applied Science, 16(4), 154-160. https://doi.org/10.3923/jas.2016.154.160

Specht, K., Weith, T., Swoboda, K., \& Siebert, R. (2016). Socially acceptable urban agriculture businesses. Agronomy for Sustainable Development, 36(17). https://doi.org/10.1007/s13593-016-0355-0

Szabo, S. (2015). Urbanisation and Food Insecurity Risks: Assessing the Role of Human Development. Oxford Development Studies. https://doi.org/10.1080/13600818.2015.1067292

Talukder, A., Haselow, N. J., Osei, A. K., Villate, E., Reario, D., Kroeun, H., ... Quinn, V. (2010). Homestead food production model contributes to improved household food security and nutrition status of young children and women in poor populations. Lessons learned from scaling-up programs in Asia (Bangladesh, Cambodia, Nepal and Philippines). Field Actions Science Reports, (1).

Tefft, J., Jonasova, M., Adjao, R., \& Morgan, A. (2017). Food Systems for An Urbanizing World. Knowledge Product. Retrieved from http://documents.worldbank.org/curated/en/454961511210702794/pdf/Food-Systems-foran-Urbanizing-World.pdf

Trendov, N. M. (2018). Comparative study on the motivations that drive urban community gardens in Central Eastern Europe. Annals of Agrarian Sciences, 16, 85-89. https://doi.org/10.1016/j.aasci.2017.10.003

Ulug, C., \&Horlings, L. G. (2019). Connecting resourcefulness and social innovation: exploring conditions and processes in community gardens in the Netherlands. Local Environment, 24(3), 147-166.

United Nations. (2018a). The speed of urbanization around the world.

United Nations. (2018b). World Urbanization Prospects: The 2018 Revision.

Wu, C., \& Chang, S. E. (2018). Social Designing Edible Community Networks: Longtan, Taoyuan, Taiwan. Environment-Behaviour Proceedings Journal, 3(7), 103-111. https://doi.org/https://doi.org/10.21834/ebpj.v3i7.1283 